\title{
PODER E ORDEM NA FORMAÇÃO DA MODERNIDADE: UMA ABORDAGEM GENEALÓGICA DA LEI
}

\author{
PODER Y ORDEN EN LA FORMACIÓN DE LA MODERNIDAD: UN ABORDAJE \\ GENEALÓGICO DE LA LEY
}

\author{
POWER AND ORDER IN THE FORMATION OF MODERNITY: A GENEALOGICAL APPROACH \\ TO THE LAW
}

\section{ORDRE ET POUVOIR DANS LA FORMATION DE LA MODERNITÉ : UNE APPROCHE GÉNÉALOGIQUE DE LA LOI}

DOI: $10.5533 / 1984-2503-20124302$

Vinicius Bandera ${ }^{1}$

\section{RESUMO}

Pretendemos defender que a modernidade ocidental, apesar do grande salto tecnológico produzido pela fábrica e, mais recentemente, pelo computador, ainda é fortemente guiada por valores judaico-cristãos e racionalistas gregos, ambos ancorados no universalismo, verdades absolutistas e dominações materiais sustentadas por dominações imaginárias. Palavras-chave: modernidade, ordem, dominação.

\section{RESUMEN}

Pretendemos defender que la modernidad occidental, a pesar del gran salto tecnológico producido por la fábrica y, más recientemente, por la computadora, todavía es

\footnotetext{
${ }^{1}$ Pós-doutorando em História Social pela USP (2012). Autor do livro Liberalismo e cientificismo: conflito de paradigmas na correção/proteção de menores na virada do século XIX para o XX, (Editora UFRJ, no prelo). E-mail: viniciusbandera@gmail.com
} 
fuertemente guiada por valores judeo-cristianos y racionalistas griegos, ambos fundamentados en el universalismo, verdades absolutistas y dominaciones materiales sostenidas por dominaciones imaginarias.

Palabras-clave: modernidad, orden, dominación.

\begin{abstract}
We aim to argue that western modernity, in spite of the great technological leap produced by industry, and more recently, by computers, is still strongly guided by Judeo-Christian and rationalist Greek values, both anchored in universalism, absolutist truths and material dominations sustained by imaginary dominations.
\end{abstract}

Key words: modernity, order, domination.

\title{
RÉSUMÉ
}

II s'agit ici de défendre que la modernité occidentale, en dépit du grand bond technologique représenté par l'industrie, et plus récemment, par l'informatique, est encore fortement guidée par des valeurs judéo-chrétiennes et le rationalisme grec, c'est-à-dire ancrée dans l'universalisme, dans des vérités absolutistes et dans des dominations matérielles sous-tendues par des dominations imaginaires.

Mots-clés: modernité, ordre, domination.

\section{Introdução}

Para abordarmos a questão do poder e da ordem na modernidade, faz-se necessário procedermos tal objetivo através de uma leitura genealógica, por entendermos que tal questão não tem como origem a modernidade, mas um longo processo histórico que a precedeu e a conformou. Com isto, fica evidente que a nossa abordagem tem a genealogia nietzscheana como parâmetro de investigação, pelo qual identificamos duas origens fundadoras do projeto de modernidade: a cultura grega e a cultura judaico-cristã. Ambas tendo em comum e legando à modernidade valores de universalismo, verdades absolutistas e dominações materiais sustentadas por dominações imaginárias ou imateriais, tudo isto servindo de arrimo para uma doutrina de juízo. Procuraremos mostrar, 
a exemplo de Nietzsche, que todo projeto societário, expresso por poder e ordem, está amparado por valores criados por elites (e não pelo todo social, menos ainda por seres transcendentais) em um determinado momento histórico. Valores que podem mudar de sociedade a sociedade, de época a época, sendo, portanto, perspectivos, a despeito de serem passados (por elites) como os únicos possíveis, absolutistas. Quanto mais uma sociedade busca se guiar por valores transcendentais, mais é possível perceber 0 perspectivismo desses valores, pelo fato concreto deles variarem de sociedade a sociedade.

A modernidade herdou das culturas grega e judaico-cristã a doutrina do juízo, pela qual o poder e a ordem são permeados por uma relação credor-devedor, que inculca neste último um sentimento de dívida para com o primeiro, por considerar-se culpado a priori. Na cultura judaico-cristã, essa relação coloca Deus de um lado e os homens de outro, tendo como origem os mitos da criação e do pecado original. Pelo fato de os homens terem em si o pecado original, eles já nascem culpados e com uma dívida que irá se tornar cada vez mais pesada à medida que forem adquirindo mais pecados ao longo da vida. Esse sentimento de culpa gera uma dominação imaginária que serve de base a uma dominação material e concreta. Na cultura grega, o paradigma de doutrina de juízo que melhor serviu de espelho para a modernidade foi o formulado por Platão através de seu entendimento de uma vida humana dualista: o mundo das ideias e o mundo das formas, sendo este constrangido a adequar-se à ordem daquele. Com base nessa dualidade, Platão criou um mundo humano idealizado, o qual tem como modelo $A$ república, na qual todas as pessoas são ordenadas de modo a cumprirem uma determinada função pré-estabelecida. Ao invés de estarem em dívida com Deus (ou deuses) os homens platônicos se sentem em dívida com a lei racional. Em ambos os tipos de dominação, há uma ideia de transcendência, universalismo e verdades absolutistas. A modernidade originou-se da refutação aos mundos feudal e absolutista e, concomitantemente, da apropriação e adequação dos valores gregos (e também

romanos) e judaico-cristãos para seus fins de poder e ordem. É o que pretendemos demonstrar ao longo deste trabalho.

\section{O Estado}

O senso comum costuma ter a impressão de que uma determinada ordem social, sobretudo aquela na qual estamos inseridos, é algo ontológico: é por que é, não poderia 
ser diferente, um ser em si e por si, a exemplo de uma lei natural. Essa impressão é reforçada por anos, décadas, séculos, de imposição prática e teórica dessa ordem, fazendo com que ela tenha uma história oficial, a qual também é apresentada (pelos ordenadores) como sendo a única possível, a verdade dos fatos. Para se impor uma determinada ordem é fundamental que uns tenham mais poder que outros. É necessário que haja dominação. Isto por que a ordem, em geral, não vem de todos, mas dos que concentram poder em detrimento dos que não concentram. Não se trata, portanto, de uma ordem oriunda de consenso, como nos faz crer os jusnaturalistas. Vamos adotar em nossa abordagem a versão próxima da nietzscheana, segundo a qual a ordem humana é antinatural, produto de uma correlação de forças históricas e imposta por poucos contra muitos, fazendo com que estes acreditem que se trata da única ordem possível. Ordem esta que constitui uma totalidade em termos econômico, político e ideológico, sob o monopólio da classe dominante de uma determinada época histórica, como entende o materialismo histórico.

Segundo este nosso entendimento, poder e ordem se alimentam e realimentam um outro através da história, que nos indica que havendo poder e ordem surgem, por reação, contrapoder e contra-ordem, que, por vezes, geram novos poderes e ordens, que geram novos contrapoderes e contra-ordens, e assim sucessivamente. Marx e Engels vêem a história dessa maneira dialética; no entanto, defendem uma síntese final sob a forma de comunismo, o qual representa o poder e a ordem definitiva. Para Nietzsche, a história é uma correlação de forças (poderes) que combatem incessantemente para impor sua ordem, sua hegemonia. Não há, em Nietzsche, uma leitura teleológica da história, como há na literatura marxista e na grande maioria dos pensadores burgueses. Nietzsche considera que a história pode avançar ou retroceder, dependendo dos efeitos causados pela correlação de forças em um dado momento histórico. Por essa leitura, a história não tem, atavicamente, um sentido evolutivo de progresso.

Sobre a relação poder e ordem é interessante ressaltar que o poder se concentra sob a forma de macropoder, mas isto não implica dizer que ele está de posse apenas dos que o concentram. Se assim o fosse, os que não têm a concentração do poder não poderiam reagir a esse poder concentrado e instalar, ou tentar instalar uma contra-ordem. O poder está concentrado sob a forma de macropoder, cujo padrão moderno é o Estado, monopolizador do exercício teórico-prático da violência (Weber), mas também está desconcentrado em inúmeros micropoderes a cargo de membros e instituições da 
sociedade, como verificou Foucault em seus estudos arqueológicos e genealógicos. Micropoderes, que, não raramente, reforçam o poder estatal, mesmo quando o contestam.

O Estado aparece como a mais poderosa máquina territorial de poder, principal responsável legal pela produção e reprodução da ordem, atuando tanto coerciva quanto persuasivamente. Uma máquina territorial de poder que não é neutra nem um bem comum, como teorizam os liberais. Mas, como teoriza o marxismo, uma máquina a serviço da classe dominante, mesmo quando essa classe está cindida e em rivalidade entre suas partes, como analisa Marx em O dezoito brumário de Luis Bonaparte. Um Estado que, segundo o marxismo, origina-se de lutas de classes. Origina-se, portanto, da violência, e não de contratos consensuais para reproduzir uma ordem consensual que já existia em um fictício estado de natureza. Por baixo e para além da idílica e civilizada versão contratualista, Nietzsche divisa barbárie, selvageria:

Emprego a palavra 'Estado', mas é fácil compreender que me refiro a uma horda qualquer de aves de rapina, uma raça de conquistadores e de senhores, que, com a sua organização guerreira deixaram cair sem escrúpulos as suas formidáveis garras sobre uma população talvez infinitamente superior em número, mas ainda inorgânica e errante. Tal é a origem do 'Estado'; creio que já foi bastante refutada aquela opinião que fazia remontar a sua origem a um 'contrato'. Ao que nasceu para mandar, ao que se sente poderoso no seu ademane e na sua obra, que Ihe importam os contratos?

Deleuze \& Guattari, corroborando Nietzsche, também entendem que o Estado foi produzido e vem sendo reproduzido pela violência:

(...)Pode ser que, espiritual ou temporal, capitalista ou socialista, não tenha nunca existido senão um Estado, o cão-Estado que 'fala por fumaça e uivos'. E Nietzsche sugere como procede esse novo socius: um terror sem precedente, em relação ao qual o antigo sistema da crueldade, as formas de doma e do castigo primitivo não são nada. ${ }^{3}$

\section{Alteridade, representação e imaginário}

O poder e a ordem têm a dominação como pressuposto. A dominação é o amalgama, a liga entre o poder e a ordem. Não há poder e ordem se uns não são dominados por outros. Uns que são muitos e outros que são poucos. A dominação pode

\footnotetext{
${ }^{2}$ Nietzsche, Friedrich (s.d). A genealogia da moral, Rio de Janeiro: Ediouro, p.78-79.

${ }^{3}$ Deleuze,Gilles \& Guattari, Félix (1976). O anti-édipo, Rio de Janeiro: Imago, p.243.
} 
dar-se a nível real concreto (material), a nível imaginário (imaterial) ou ambos concomitantemente, que é o que geralmente acontece em uma ordem estabelecida.

Outro pressuposto que podemos destacar na ordem é o seu interesse ideologizado em distinguir cultura de natureza, valorizando a primeira em detrimento da segunda. A ordem humana não tem a natureza, o mundo natural, como habitat de origem, como supõe os jusnaturalistas, mas o mundo social. É no mundo social, e não no natural, que a moral equivale a valor. Adão e Eva não seriam pecadores, nem nós por extensão, caso fossem regidos por leis naturais, mas o que os regeu foi uma lei social (judaica), travestida de lei transcendental. Nietzsche entende a moral como um valor social, próprio de uma dada sociedade e de uma dada época. Na natureza não há ideia nem de moral nem de tempo, datação. O platonismo e a tradição judaico-cristã são exemplos de abstração à dicotomia natureza-cultura em favor da transcendência, a qual fazem descer à terra para organizar a ordem social por meio de valores ditos transcendentais, que, a rigor, são sociais na origem, na produção e na reprodução da ordem.

A ordem se ergue contrapondo-se, primeiramente, à ordem da physis. Para criar a ordem, o homem, ao contrário dos outros animais, desvinculou-se da natureza, transformando-a para seus fins e, assim o fazendo, provocou transformações sociais e ideológicas, como assinala Marx em $O$ capital. A ordem é afirmativa, mesmo quando nega a existência terrena em favor de uma existência sobrenatural, como ocorre com Platão e a tradição judaico-cristã. Ambos não defendem ordens afirmativas no sentido de afirmar a vida material humana, como denuncia Nietzsche; no entanto, são extremamente afirmativos no sentido de se esforçarem a não deixar margens a dúvidas quanto ao que pode e o que não pode ser. São doutrinas ordenadoras que se sustentam em uma alteridade diríamos parmenediana: o ser é e o não-ser não é; nós e eles. Têm também em comum com Parmênides a imutabilidade perene. Marx e Nietzsche, por outro lado, têm uma raiz heraclitiana; uma grande diferença é que o segundo não contempla na história um sentido de progresso.

A maior sustentação da ordem não está propriamente nela, mas na negação do outro, através de uma relação de alteridade. O poder de Deus se torna tanto mais forte quanto mais forte for contraposto ao poder do Diabo, que não pode ser um poder qualquer, mas um poder superpoderoso, mesmo que imaginário, para justificar o poder ainda mais poderoso de Deus. O Deus dos hebreus aparece como sendo inimigo dos deuses de outros povos, o que fortalece imaginariamente a inimizade dos hebreus em 
relação a outros povos, e vice-versa. Da mesma forma ocorre na modernidade com as oposições do capitalismo ao socialismo, e vice-versa. É fundamental para a manutenção da ordem a criação do que Hanna Arendt denomina inimigo objetivo. O inimigo objetivo da vocação de grandeza nazista, segundo Arendt lê o nazismo, eram os judeus. O inimigo objetivo do socialismo é a burguesia. Quanto mais poderoso for o inimigo, ou quanto mais poderoso e ameaçador os ideólogos da ordem fizerem esse inimigo parecer ser, mais poderosa deve ser a argumentação de autoridade para subjugar tal inimigo e, concomitantemente, para produzir e reproduzir a ordem em uma determinada comunidade. Provavelmente por isso Marx e Engels, em $O$ manifesto comunista, enaltecem a grandiosidade da burguesia para colocar sobre esta classe o terrível peso de ser extremamente perigosa (por seu domínio tecnológico, científico e de reprodução incessante do capital) e, o que é mais grave, caudatária do poder de dar seguimento à tradição de não abolir a exploração de classes, mas edificá-la sob uma nova ordem. Do outro lado da relação de alteridade, como valor de "bom" e "bem", poderia dizer Nietzsche, eles colocam o proletariado, que nada tem a perder, a não ser seus grilhões, e que tem a missão histórica de libertar não somente a si, mas principalmente a humanidade. O proletariado aparece como uma espécie de Cristo do marxismo. Embora o marxismo seja uma contra-ordem à ordem burguesa, ele se propõe a ser uma ordem, nova ordem, produtora do novo homem, sem propriedade privada dos meios de produção, sem alienação, sem classes e sem Estado. Mesmo que o proletariado não tenha, até o momento, revelado-se o agente revolucionário preconizado por Marx, Engels, Lênin e outros autênticos marxistas, a burguesia continua, nos discursos de socialistas, e até de pseudosocialistas, a ter os valores de "mau" e "mal".Parece, no entanto, que a não consecução do socialismo autenticamente marxiano deveu-se mais à habilidade da burguesia em implantar no mundo imaginário das classes dominadas a impressão de que ela não é o inimigo objetivo; pelo contrário, é a classe que propõe (e impõe) um contrato consensual, um mundo societário no qual todos, independentemente de sua condição social, ganham. Esta é a proposta básica do contrato lockeano, o qual prevalece até hoje sob o capitalismo, em detrimento do contrato rousseauniano, que tem um germe socialista em si: a igualdade política através da democracia direta. O contrato lockeano, bem mais pragmático, contempla o que mais almejava a burguesia, sob o Absolutismo: a liberdade individual, traduzida pelo direito inalienável à propriedade: do corpo, da expressão do pensamento e dos meios de produção. O contrato rousseauniano, a despeito de ser bem 
mais radical no que tange à igualdade de todos perante à lei (cada um é juiz de si e de todos simultaneamente), restringe a liberdade individual pela liberdade coletiva, esta identificada pelo Estado, visto como um bem comum, uma vontade geral. No capitalismo, qualquer pessoa sem uma consciência crítica (Gramsci) aguçada, absorve a convicção ideologizada (passada através de discursos orais e escritos) de que a liberdade e a igualdade estão na mesma proporção para todos, sendo todos cidadãos com o mesmo grau de cidadania. Esses discursos têm um imenso poder de ordenar o mundo imaginário das pessoas, fazendo com que os que estão em um baixo nível concreto de cidadania, acabem se sentindo em dívida com aqueles (os poderosos, os capitalistas) que lhes concedem uma liberdade e uma igualdade (perante à lei) na mesma proporção que a dos ricos. Se a liberdade e a igualdade são para todos na mesma proporção, quem delas não se locupleta é, então, culpado; esta é a leitura imposta pelos discursos ideologizados. Leitura esta que se assemelha à leitura dos discursos religiosos: você tem livre-arbítrio de escolher entre o céu e o inferno, dependendo de sua fé e do que realizar diante da palavra sagrada. A culpa é sua pelos seus sofrimentos aqui na terra e no futuro inferno, poderíamos, assim, parafrasear Nietzsche. A liberdade imaginária no capitalismo é tão poderosa que até o próprio mercado, base material de sustentação deste modo de produção, é tido como livre e regido por uma espécie de ente sobrenatural: a mão invisível, como nos induz a crer Adam Smith. Dito isto, podemos inferir que a imposição de uma ordem se alicerça, geralmente, por duas vias: material e imaginária.

Provavelmente a dominação no estado de natureza se dava predominantemente por meio da força física e da astúcia selvagem de cada homem, como disserta Hobbes. A dominação a nível imaginário só veio a sobressair-se mais tarde quanto mais o homem se desenvolvia racionalmente, tendo a religiosidade como elemento fundamental. A religiosidade, mesmo quando não conduzida pela religião, como é o caso de Platão, apóia-se no transcendentalismo, o qual impõe a dualidade mundo social e mundo metafísico, o que implica, por conseguinte, a dualidade corpo e alma (mente e espírito). A dominação imaginária atua sobre a alma para dominar o corpo. Essa dominação exige um sofisticado grau de racionalidade de uma dada comunidade, sociedade. Evidentemente que quem se apropriou desse tipo de dominação foi os dominadores, os ordenadores, concentrando em si um imenso poder através dos tempos, suscitando nos dominados um complexo de culpa enquanto essência humana, não lhes restando senão seguir a ordem, as normas, a moral, imposta por essa dominação, para bem se conduzirem na terra com 
vistas a uma futura salvação sobrenatural. Essa dominação imaginária não tem valores somente religiosos ou metafísicos, mas também está ancorada em valores especificamente mundanos, introjetando nos dominados a sensação de que são inferiores devido à sua condição social subalterna (em termos econômicos, políticos e ideológicos) em relação à condição social protagonizada pelos dominadores. Esse tipo de dominação a nível imaginário, psicológico, apóia-se mais na crença de que uns são superiores e outros inferiores do que no poder de coerção. Tanto é que os poucos "superiores" armam os muitos "inferiores" para lutar contra os seus (dos "superiores") inimigos e os "inferiores" não fazem valer o seu poder de grande maioria armada para se livrar da dominação e implantar uma nova ordem, a seu favor. Essa dominação a nível imaginário, no período pré-capitalista, não era puramente material, pois no âmago da mesma, animando-a, estavam deuses de valores específicos (guerra, paz, amor, beleza, luxúria...), variando de sociedade a sociedade, até evoluir para o deus único. Em quase todas essas sociedades era imposto imaginariamente que se guerreava por ordem e a serviço dos deuses. Nessa lógica, estava embutida outra relação de alteridade: nós (amigos, nação) e eles (inimigos, contra nossa nação). Relação esta que revigorava a primeira relação de alteridade, a interna, que se traduzia na dominação de "inferiores" por "superiores". Essa dominação dificilmente se sustentaria em uma sociedade nômade. Ela necessita de seu locus social específico, sobretudo para contrapor-se, imaginária e/ou concretamente, a outros loci sociais. Surgiram, então, práticas e conceitos de comunidade, propriedade privada, povo, nação, Estado, nós e eles, nossa cultura e a deles, nossos deuses e os deles. A identidade foi deixando de ser entre os humanos e os outros animais, como no estado de natureza, para ser entre o pertencimento a um dado território, a uma dada comunidade, e o não-pertencimento. Existindo o território existem os que exercem a dominação e, consequentemente, o controle da ordem sobre esse território, em detrimento dos demais comunitários. Dominação não somente em termos de posse privada sobre bens materiais produtores e reprodutores de riqueza, mas também em termos de lei de posse, a qual se estende para todos os que vivem nesse território. Dessa dominação, resultou, como entendido por Marx, o surgimento das classes e do Estado, este como um território superestrutural sob a dominação de poucos contra muitos. 


\section{A escrita e a lei}

Outro elemento preponderante de dominação é a escrita. O que está escrito tem muito mais possibilidade de se estender no tempo e no espaço do que o que é falado de alguns para alguns. O que está escrito tem bem mais valor como "verdade", como lei, como moral, do que a oralidade. Se Moisés tivesse apenas falado aos seus pares sobre os dez mandamentos e a imperiosidade de cumpri-los, por de Deus serem oriundos, talvez eles não tivessem tido o mesmo impacto e durabilidade temporal que tiveram (e continuam tendo) pelo fato de terem sido escritos. Poucas pessoas conheceram Moisés em sua época, e ninguém, salvo casos sobrenaturais, o conheceu depois, mas ele e seus mandamentos, ditos vindos de Deus, estão representados para nós há centenas de anos, não sabemos se de forma verdadeira ou com alguns excessos e/ou subtrações, provocando considerável influência nas leis e na ordem modernas. O indubitável é que temos uma história oficial de Moisés, Abraão, Noé, Davi, Salomão, Jesus, Maomé, Sócrates, Platão, Aristóteles, Alexandre e muitos outros basicamente por causa da escrita, a qual glorifica ou desqualifica ad eternum não somente humanos, mas, aqui o mais importante, suas culturas, seus valores, impondo ao futuro um processo civilizatório segundo uma dada (e imposta) história oficial. A escrita, cremos, representa o ápice da dominação (imaginária e material) a serviço de uma dada ordem. Não sabemos quem foi Jesus de fato, mas somos reféns de sua representação que a história (escrita) oficial nos impôs. E dessa representação se apropriaram, adaptando-a para fins de dominação, até os que crucificaram Jesus, os romanos entre os mais destacados, que nos legaram essa apropriação. Com a escrita, o homem passou a ter o poder de um deus, concreto, real, material, mesmo quando apóia sua dominação em fatos e narrativas imateriais. Eu agora tenho a palavra escrita (uma lei material ou imaterial, por exemplo) e posso usá-la como argumento de autoridade mesmo que eu não a tenha lido ou que a tenha lido superficialmente ou saiba dela por fontes orais e/ou escritas secundárias. O que importa não sou eu, mas o poder que tenho de usar a palavra escrita, brandi-la, se for o caso. $O$ meu poder não decorre de mim, mas da crença dos que crêem na palavra escrita. Se eu brandi-la para os que nela não crêem, corro o risco de ter a cabeça cortada como João Batista. 


\section{Crença e fé}

A crença é, portanto, outro poderoso elemento de dominação, imaginário, o qual, no mais das vezes, equivale a uma ilusão. Cada cultura tem suas crenças. Se deuses específicos são sacralizados em uma cultura, podem ser execrados em outras. O Deus dos hebreus era idolatrado por estes e desprezado pelos egípcios, por exemplo. Jesus, que tanto valor tinha para seus seguidores, foi ridicularizado, desprezado e crucificado pelos romanos, para os quais ele era oficializado como sendo um malfeitor, tendo os valores de "mau" e "mal". Um socialista é torturado por seus algozes que têm uma crença anti-socialista. Da mesma forma um opositor a um regime socialista. A fé é algo abstrato, que não existe materialmente. A fé é a sensação da crença, sendo ambas transmitidas de gerações a gerações. A crença é o acreditar em algo que não pode ser medido materialmente, mas que pode ser partilhado em igual proporção por uma dada coletividade. A fé também não pode ser medida materialmente e só pode ser sentida individualmente, cada pessoa com sua proporção particular de fé. Nesse sentido, a fé de Abraão é bem maior do que a fé de Pedro. Ninguém nasce com crenças e fez, ambas são inculcadas culturalmente desde a mais tenra infância como verdades inquestionáveis, dogmas, símbolos de poder e, consequentemente, de obediência. Duas pessoas que nascem no mesmo dia e hora em culturas diferentes poderão ter crenças e fez diferentes e até antagônicas, fazendo-as entrar em futuros conflitos. A dominação pela crença/fé é geralmente imposta desde a infância por que é nesse momento que a pessoa está mais suscetível de um aculturamento, pois está praticamente vazia em termos de tomada de consciência do mundo, sem querermos com isto endossar integralmente a tese da tabula rasa de Locke. Se a crença religiosa, ou outra qualquer não baseada em experiências concretas, fosse transmitida na fase adulta das pessoas, haveria menos probabilidade de êxito dela se tornar aceitável do que quando se é transmitida na infância. O homem é predisposto a crer no que não conhece materialmente porque é mais fraco do que a natureza, necessitando, portanto, de algo fora de si que lhe dê forças para suportar sua frágil existência, de cuja origem ele não participou. O homem é um ser fraco em conhecer e fraco em se defender, daí sua necessidade de saberes materiais e imateriais, de concretudes e ilusões. A religião representa uma função importante em atender demandas humanas no sentido de buscar explicar o desconhecido e servir de amparo a fraquezas humanas. Ela ocupa um vasto espaço de nosso mundo imaginário e se expressa como dominação imaginária do superego sobre o ego. No entender de Freud, 
"as idéias religiosas são ensinamentos e afirmações sobre fatos e condições da realidade externa (ou interna) que nos dizem algo que não descobrimos por nós mesmos e que reivindicam nossa crença" ${ }^{\text {". }} \mathrm{O}$ importante para Freud não é considerar se essas ideias são verdadeiras ou falsas, mas que elas são ilusões que expressam "realizações dos mais antigos, fortes e prementes desejos da humanidade,

Como Kant em Crítica da razão pura, que sustenta que não é possível racionalmente provar a existência nem a não-existência de Deus, Freud considera que as ideias religiosas não podem ser provadas nem refutadas. ${ }^{6}$ e que a modernidade deve contrapô-las com a ciência, que é "a única estrada que nos pode levar a um conhecimento da realidade externa a nós mesmos" $"$.

\section{Trabalho, mito e doutrina do juízo}

Com a saída do homem do estado de natureza, o trabalho errante e fortuito de cada um perdeu autonomia e se transformou em trabalho social, possibilitando uma relação de dominação de muitos por poucos. A dominação através do trabalho não se efetua apenas através do corpo, mas também da mente, sobretudo pela imposta (pelos poucos) separação (não natural, mas social como analisam Marx e Engels em $A$ ideologia alemã) do trabalho em duas vertentes: trabalho manual e trabalho intelectual. Com essa separação, ocorrida através do processo civilizatório, não é difícil entender que os poucos dedicados ao trabalho intelectual estão, em sua grande maioria, a serviço da ordem contra os muitos dedicados ao trabalho manual. A dominação intelectual implica dominação em termos de concepções de mundo (Gramsci), tanto as materiais quanto as imateriais. Durante o século XX, Adorno, Hokheimer e Marcuse, entre outros, demonstrariam o quanto a indústria cultural representa um tipo de dominação intelectual imposta por poucos a muitos.

Assim como as religiões, os mitos são fortes fontes de dominação no sentido de se edificar e conservar uma ordem. O mito, como a religião, não é uma mentira, mas a versão irracional (mas construída racionalmente por elites ilustradas) de uma dada

\footnotetext{
${ }^{4}$ Freud, Sigmund (1978). "O futuro de uma ilusão". In Freud, Sigmund (1978). Cinco lições de psicanálise; história do movimento psicanalítico; o futuro de uma ilusão, o mal estar da civilização; esboço da psicanálise, São Paulo: Abril Cultural, p.103.

${ }^{5}$ Ibidem, p. 107.

${ }^{6}$ lbidem, p. 108.

${ }^{7}$ Ibidem.
} 
realidade material. É, em outras palavras, a imaterialidade de uma realidade material. $\mathrm{O}$ mito da criação, versado na Bíblia, por exemplo, antes de podermos considerá-lo uma mentira, devemos considerá-lo como um instrumento para fundar a dívida nos crentes da moral (bíblica, judaica) instituída pela casta judaica. Fundar a dívida como efeito da culpa. Ou seja, é fundamental entender esse mito como uma relação de causa (culpa) e efeito (dívida). O mito é irracionalizado enquanto história mítica, mas é extremamente racionalizado enquanto construção lógica exterior a essa história. A construção vem de fora do mito: vem de um pequeno e seleto (do ponto de vista intelectual e de dominação material) grupo judaico. É uma construção racional não somente por que se apóia em uma relação (racional) de causa e efeito, mas por que, e principalmente, serve a fins determinados; no caso, fins de dominação, de impor uma determinada ordem, e não ordens aleatórias. Não é um mito gratuito, fortuito. É mito religioso, metafísico, com conteúdo e intenção materiais. O mito primeiramente descreve um Deus criador de tudo e de todos, com o fito benevolente de estabelecer uma ordem perfeita e boa (no sentido genealogicamente judaico de promotora do "bom" e do "bem") não somente para as criaturas humanas, mas para as demais. No entanto, o homem e a mulher (sobretudo esta, vista à época da criação do mito da criação como inferior ao homem) traíram essa boa intenção de Deus, tornando-se culpados, portanto devedores. Como ainda não havia o liberalismo (centrado na responsabilidade tão-somente individual), essa culpa e dívida se estenderam para todos os descendentes desse homem e dessa mulher. Ou seja, todos os homens e mulheres futuros que absorveram culturalmente esse mito. Os que não o absorveram estão salvos. Não salvos das atribulações vaticinadas pelo mito (sofrer as dores do parto, caso específico da mulher; sobreviver à custa do suor; morrer...), mas salvos de nele crer e deixar-se pautar sua vida pela moral (bíblica) que estabelece tal mito e a relação de causalidade envolvendo a culpa e a dívida.

No mito da criação está embutido o mito do pecado original, que é um elemento de dominação expresso pelo poder dos sacerdotes em nome de um poder maior e transcendental: o poder de Deus. O pecado original introjeta nos homens a ideia de que eles são culpados a priori e, portanto, têm uma dívida para com o criador, esta é a leitura que Nietzsche faz da relação de causalidade envolvendo culpa e dívida. Uma relação que está circunscrita não somente ao período pré-moderno, mas também no seio da modernidade, a despeito da morte (como valor) de Deus. Para Nietzsche, a moral judaicocristã é uma criação da casta judaica, do mesmo modo que a moral grega é uma criação 
de elites gregas, sobretudo Platão e seu alter-ego Sócrates. Na primeira, o valor supremo a reger a sociedade é Deus, na segunda é a justiça representada como uma das virtudes fundamentais do homem. Em ambas, o poder da lei governa os homens: o poder da lei irracional (Deus) e o poder da lei racional humana. A diferença essencial é que no caso judaico um ser ontológico (Deus) equivale à lei, no segundo a lei humana assume um nível ontológico em lugar de Deus. Em ambas as morais, há o estabelecimento de um a priori sentimento de culpa, do qual Freud faz uma interpretação próxima da de Nietzsche, tendo-o como uma "tensão entre o severo superego e o ego, que a ele se acha sujeito". Os indivíduos têm esse sentimento de culpa por que sentem que têm uma dívida a priori para com um superego material e/ou imaterial, o que gera uma relação credor-devedor que vem atuando com imenso poder para a sustentação de ordens ao longo da história, como nos indica Deleuze/Guattarri:

Toda estupidez e o arbitrário das leis, toda a dor das iniciações, todo o aparelho perverso da repressão e da educação, os ferros rubros e os procedimentos atrozes só têm esse sentido, domar o homem, marcá-lo na sua carne, torná-lo capaz de aliança, formá-lo na relação credor-devedor que, dos dois lados, resulta ser um assunto de memória (uma memória tendida para o futuro). Longe de ser uma aparência que toma a troca, a dívida é o efeito imediato ou meio direto da inscrição territorial e corporal. ${ }^{9}$

\section{Racionalidade burguesa tornada lei}

Com a modernidade, a razão passa a servir de parâmetro fundamental para orientar a lei, a qual ganha um grau bem maior de objetividade, se comparado com tempos pré-capitalistas, e se torna princípio supremo em lugar de Deus, sem deixar de estabelecer a relação de causa e efeito pela qual o culpado (diante da lei que o enquadra antes mesmo dele cometer o delito) está em dívida com a sociedade, não mais por um motivo imaterial (pecado original), mas por um motivo material (o delito cometido). Assim se expressa de forma contundente a dominação imaginária no mundo moderno, constituindo um fundamental elemento garantidor da ordem. Nessa relação de causalidade, produzida por essa dominação imaginária, está implícita a noção objetiva de

\footnotetext{
${ }^{8}$ Freud, S. (1978). "O mal-estar na civilização". In Freud, Sigmund (1978). Cinco lições de psicanálise; história do movimento psicanalítico; o futuro de uma ilusão, o mal estar da civilização; esboço da psicanálise, São Paulo: Abril Cultural, p.176.
}

${ }^{9}$ Deleuze, G. \& Guattari, F. (1976). Op. cit., p. 241. 
dever: eu devo obedecer à lei previamente estabelecida à minha revelia. $\mathrm{O}$ conceito kantiano de imperativo categórico é, provavelmente, a mais bem acabada tradução dessa noção de dever objetivo e constitui o mais bem acabado elemento de dominação da ordem moderna. A ética do dever, em Kant, é representada por dois tipos de imperativos: hipotéticos e categóricos. O imperativo hipotético é condicionado por algo empírico e equivale a um meio para se alcançar um fim. Exemplo: eu devo fazer "a" para alcançar "b". É, portanto, um imperativo subjetivo. Já o imperativo categórico é um fim em si mesmo, e não um meio para se alcançar um fim: eu devo fazer "a" incondicional e objetivamente, mesmo que a minha vontade escolha uma outra opção mais confortável para mim. O imperativo categórico é regido pelo princípio da universalidade: "age apenas segundo uma máxima tal que possas ao mesmo tempo querer que ela se torne lei universal"10. Essa universalização decorre do fato, segundo Kant, de que todos os seres humanos são racionais e têm uma mesma natureza humana. O imperativo categórico é instrumento fundamental para garantir a ética kantiana, garantir a ordem racional em uma sociedade baseada em um contrato liberal de base lockeana. Se vigorasse a ética do imperativo hipotético, o subjetivismo se imporia ao objetivismo, abrindo possibilidades amplas a permanentes conflitos de vontades e de valores. O imperativo categórico equivale à razão prática pura e o hipotético à razão prática empírica. Para Kant, o primeiro impera sobre o segundo, havendo uma "prioridade da razão prática pura sobre a razão prática empírica" ${ }^{\text {"11 }}$, fazendo com que a lei moral seja "uma ideia da razão"12.

\section{Conclusão: doutrina do juízo e verdade sob suspeita}

Pelo que vimos até aqui, podemos reiterar que a ordem moderna, enquanto projeto, é caudatária de dois poderes protomodernos: o Deus único judaico-cristão e a racionalidade grega. O Deus único representa a ordenação da confusão de representações por que passava a Antiguidade em tempos pretéritos à construção desse Deus. Com tal confusão de representações, os poderes se tornam dispersos, dificultando

\footnotetext{
${ }^{10}$ Kant, Immanuel (1988). Fundamentação da metafísica dos costumes, Lisboa: Edições 70, p.59.

${ }^{11}$ Rawls, John (2005). "O imperativo categórico: a primeira formulação". In Herman, Bárbara (Org). História da filosofia moral, São Paulo: Martins Fontes, p.195.

${ }^{12}$ Ibidem, p.192.
} 
a imposição (coerciva e persuasivamente) de uma ordem totalitária (no sentido de abranger e fundamentar todos os códigos sociais e não permitir oposições que possam vir a desconstruí-los). Esse Deus único, embora dito (pela casta judaica) ser exclusivo dos judeus, deixou de ter o caráter particularizado dos deuses de outras civilizações antigas para assumir um caráter de universalidade. Caráter esse que também viria a ser assumido pela burguesia em sua construção do mundo moderno. Nesse sentido, é importante a contribuição de Weber, em A ética protestante e o espírito do capitalismo, que detectou uma conjugação de valores, capitalistas e protestantes (herdeiros da tradição judaico-cristã), na construção da modernidade.

Há um imaginário dominante, inculcado em nós, modernos, através da formação escolar, sobretudo esta, impondo uma verdade segundo a qual a modernidade é um corte com o passado. Assim, aprendemos que a modernidade instaura uma nova verdade na história humana. Verdade essa responsável pelo desmascaramento da verdade anterior, a qual correspondia a uma interpretação de que o mundo real era uma decorrência de um mundo imaginário (transcendental), estando ambos os mundos sob a mesma dominação (imaginada pelos formuladores dessa interpretação): Deus. Essa verdade anterior equivalia à teologia, que foi fundada e desenvolvida com base no judaísmo-cristianismo (Sagradas Escrituras), equivalente à verdade revelada, que podemos entender como sendo a verdade imaginada (pela fé), e o arcabouço racionalista grego, basicamente representado por Platão e Aristóteles, além de alguns discípulos seus. Da mesclagem de judaísmo-cristianismo com platonismo, surgiu a patrística, tendo Agostinho como seu maior representante. O judaísmo-cristianismo com aristotelismo gerou a escolástica, cujo principal nome foi Tomás de Aquino. Menos do que corte ou descontinuidade, percebe-se que nessa passagem do mundo antigo ao medieval, em que pese significativas transformações em termos de valores, costumes e organização social, houve uma continuidade fundamental, traduzida pelo que até aqui vimos argumentando: a ideia imposta de uma verdade universal (para os gregos clássicos, extraída da razão; para o judaísmo-cristianismo, extraída da revelação) e a ideia de a dominação material ser fruto de uma dominação imaginária (em Platão, a dominação imaginária é amparada em sua teoria das ideias; no judaísmo-cristianismo, é amparada também na revelação). Havendo ambas as ideias, houve, por consequência lógica, continuidade da doutrina do juízo, e até um reforço desta, em virtude do fundamentalismo religioso que marcou o mundo medieval. 
Isto posto, é interessante voltarmos à visão dominante de que a modernidade instituiu um corte com o passado. Precisaríamos de muito mais tempo e espaço do que o que aqui dispomos para tentar elaborar uma argumentação dando conta de que, em termos essenciais, somos uma continuidade, sob outra roupagem, dos valores judaicocristãos e do racionalismo grego, ambos tendo por arrimo verdades universais e dominações materiais derivadas de dominações imaginárias. Para buscarmos sintetizar essa pretensa argumentação, tomemos o pensador tido como fundador do ideário de modernidade, Descartes, que desenvolve um engenhoso esforço argumentativo, baseado em um revival da racionalidade grega, para afirmar a supremacia da razão no novo mundo que se descortinava, intentando, assim, desqualificar o fundamentalismo escolástico, que tinha como essência a dominação imaginária da verdade revelada. Não obstante defender uma razão universal e absolutista, Descartes não consegue libertar a modernidade da dominação imaginária (verdade revelada), pois o seu cogito não é autônomo, mas refém dos desígnios de Deus. Podemos compreender que na racionalidade carteseana há uma verdade universal composta de dois deuses: o deus da tradição judaico-cristã e a deusa razão, refundada por Descartes. Como ainda somos essencialmente carteseanos, a moral moderna é depositária de ambos os deuses e nos impõe uma doutrina do juízo pela qual somos dominados pelo medo de entrarmos em desacordo com as leis ditadas pela verdade revelada (tradição judaico-cristã) e pela verdade racional moderna (derivada da racionalidade grega). Se temos medo é por que nos forçaram, desde a mais tenra infância, a imaginar que somos culpados pela infração cometida ou mesmo pela tentação de cometer uma infração. Se pensamos em roubar, matar, etc. ou de fato roubamos, matamos, etc., não conseguimos livrar-nos da dominação imaginária de estarmos em culpa e, consequentemente, em dívida. Então, parece-nos que a doutrina do juízo continua em nossa formação, ancorada tanto na verdade da lei de Deus quanto na verdade da lei dos homens. Assim, essa dominação imaginária que nos acomete serve de base psicológica para a dominação material representada pela lei positiva. Esse é o drama do protagonista de Crime e castigo, de Dostoievsky, que se sente dominado pela imaginação de ter afrontado a lei de Deus e a lei dos homens, sendo por isso culpado e devedor. Não por acaso, mas por intenção de dominação, que Kant, o sistematizador da lei moderna, apela para que imaginemos - em um exercício transcendental - que temos (por dever objetivo) que ser guiados pelo 
imperativo categórico, o qual nos prende à verdade e à doutrina do juízo, e não pelo imperativo hipotético, que nos faz imaginar razões subjetivas para transgredir a lei.

Spinoza é pioneiro, antes mesmo de surgir a modernidade, em colocar sob suspeita quaisquer arcabouços de dominação baseados em verdades absolutistasuniversalistas e em doutrinas do juízo, pelo fato primordial dele fazer Deus (da tradição judaico-cristã) equivaler à natureza. Com isso, ele retira o transcendental de cena, principal responsável pela construção de uma dominação imaginária (como detectamos há pouco em Kant), de uma verdade universalista-totalitária e de uma doutrina do juízo fundada por essa verdade e expressa pela relação culpa-dívida,credor-devedor. Spinoza refuta um deus transcendente e a própria transcendência, que não é tão-somente religiosa, haja vista que Platão e Descartes são dois grandes e fundamentais exemplos há vários outros - de transcendência laica e racional. Não há, em Spinoza, a alteridade Deus-nós, mas uma unidade ontológica, reiteramos, pela qual Deus é a natureza e nós somos partes dessa natureza. Em Spinoza, o mundo das ideias platônico e o mundo divino judaico-cristão se desvanecem. O que acontece deixa de ser efeito de causas transcendentais para ser realização de necessidades da natureza e dos homens. Sem transcendência, não há lugar para a culpa. Sem culpa, não há dívida; não há, portanto, doutrina do juízo, o que compromete a verdade.

Nietsche, indo por esse viés spinozista, é pioneiro, na modernidade, a esgrimir contra a doutrina do juízo e a verdade que a sustenta. Em seus primeiros textos, ele estava preso à noção de cultura (bildung) como universalismo oficial (formulado e a cargo das elites), como ordem estabelecida e perene, à semelhança da paideia grega (vide, por exemplo, $O$ nascimento da tragédia no espírito da música). No entanto, em 1873, ele estabelece um divisor de águas em sua carreira através do texto Sobre a verdade e mentira no sentido extra-moral, quando rompe com seu apego à certeza, à verdade e à cultura como bildung, tornando-se o Nietzsche problematizador, contestador de paradigmas, iconoclasta. Nesse texto, ele propõe uma nova noção de verdade, resultante de um jogo de forças antagônicas. Esse Nietzsche antidogmático e antimoralista perduraria até o fim de seus dias, com a crença de que "a vida não foi inventada pela moral: ela quer o engano, ela vive de engano... mas não é que já recomeço e faço o que sempre fiz, eu velho imoralista e passarinheiro - e falo 
imoralmente, extramoralmente, para além de bem e mal?"13. Um Nietzsche que aposta nos espíritos livres contra os espíritos cativos: entendidos estes como os presos a verdades, a culturas, a dogmas, ao establishment, enquanto que aqueles são o contrário: os que não "estão amarrados à verdade"14. Nietzsche, ao se tornar o Nietzsche antimoralista, teve como pressuposto de sua atividade de pensar, desde então, o atacar as verdades, morais e ordens, por estarem apoiadas em valores subjetivos de poder e datados genealogicamente. Longe de querer formular novas verdades, morais e ordens, ele se dedicou a pregar uma transvalorização dos valores, algo que só pode ser feito pelos homens além-do-homem ou super-homens. (vide, por exemplo, Assim falou Zaratustra). O Zaratustra construído por Nietzsche é um ser fora da dominação imposta por qualquer doutrina do juízo. Sem ser apegado a verdades, ele não se imagina culpado nem tampouco devedor, mas um ser que tem a si e a natureza como única lei.

A despeito dos desvios e refutações de Spinoza e Nietzsche, parece-nos que a modernidade segue sendo essencialmente influenciada por valores judaico-cristãos e pelo racionalismo grego, ambos ancorados no universalismo e na dominação material sustentada por dominações imaginárias, as quais fazem com que nos sintamos (nos imaginemos) culpados e devedores por transgredir a lei. Sendo assim, poderíamos dizer,como naquela música (Como nossos pais) do Belchior, que, "apesar de termos feito tudo, tudo, que fizemos, ainda somos os mesmos e vivemos como os nossos pais".

\section{Referências}

Deleuze, Gilles \& Guattari, Félix (1976). O anti-édipo. Rio de Janeiro: Imago.

Freud, Sigmund (1978). "O futuro de uma ilusão". In Freud, Sigmund (1978). Cinco lições de psicanálise; história do movimento psicanalítico; o futuro de uma ilusão, o mal estar da civilização; esboço da psicanálise, São Paulo: Abril Cultural, p. 85-128.

. "O mal-estar na civilização". In Cinco lições de psicanálise; história do movimento psicanalítico; o futuro de uma ilusão, o mal estar da civilização; esboço da psicanálise, São Paulo: Abril Cultural, p.129-194.

\footnotetext{
${ }_{13}^{13}$ Nietzsche, Friedrich (2000). Humano, demasiado humano, São Paulo: Nova Cultural, p.64.

${ }^{14}$ Nietzsche, Friedrich (s.d). A genealogia da moral, Rio de Janeiro: Ediouro, p.124.
} 
Kant, Immanuel (1988). Fundamentação da metafísica dos costumes, Lisboa: Edições 70.

Nietzsche, Friedrich (s.d). A genealogia da moral, Rio de Janeiro: Ediouro. (2000). Humano, demasiado humano, São Paulo: Nova Cultural.

Rawls, John (2005). "O imperativo categórico: a primeira formulação." In Herman, Bárbara (Org). (2005). História da filosofia moral, São Paulo: Martins Fontes, p. 187 -204.

Recebido para publicação em junho de 2012.

Aprovado para publicação em agosto de 2012. 